\title{
LOCAL PERSPECTIVE OF COMMUNITY PARTICIPATION IN LAKE TOBA AS A TOURISM DESTINATION
}

\author{
Kadek Wiweka $^{1 *}$, Budi Setiawan ${ }^{2}$, Suci Sandi Wachyuni ${ }^{3}$, Putu Pramania Adnyana ${ }^{4}$ \\ ${ }^{1 *}$ Doctoral Student, École Doctorale Sociétés, Temps, Territoires (EDSTT) Tourisme, Université Angers, France; \\ ${ }^{2}$ Department of Tourism and Department of Research, Politeknik Sahid, Indonesia; ${ }^{3}$ Doctoral Student, Tourism Studies \\ Programme, Universitas Gajah Mada, Indonesia; ${ }^{4}$ Assistant Professor Faculty of Humanities, University of Indonesia, \\ Indonesia. \\ Email: ${ }^{1 *}$ kadek.wiweka@etud.univ-angers.fr, ${ }^{2}$ budisetiawan@ stpsahid.ac.id, ${ }^{3}$ suci.sandi.wachyuni@mail.ugm.ac.id, \\ ${ }^{4}$ ppramania@ui.ac.id
}

Article History: Received on $30^{\text {th }}$ March 2020, Revised on $29^{\text {th }}$ April 2020, Published on $14^{\text {th }}$ June 2020

\begin{abstract}
Purpose of the study: The empowerment of local communities is currently an interesting issue in tourism development. This study aims to examine the forms of involvement of local communities in Lake Toba and to analyze their level of participation. This research begins by identifying the tourism potential of Lake Toba through the attribute theory of tourist destinations (attraction, accessibility, amenities, accommodation, and ancillary service).

Methodology: Multi-method approaches are used to examine this phenomenon. The qualitative method is conducted by non-participant observation in research locations to see the locals' behavior in Lake Toba in terms of the acceptance of tourism activities. The quantitative method is conducted by distributing questionnaires with 90 randomly chosen respondents (local communities) regarding their perspective toward their participation in tourism development. The collected data will be processed and combined and will also be studied using Arnstein's model as the main measuring instrument in discussing the level of local community participation in the destination.
\end{abstract}

Main Findings: The result of this research is that Lake Toba has the potential to attribute tourist destinations on the 5A system. In terms of the level of local community participation, the community response to its involvement in tourismdestination attributes in Lake Toba can be categorized in the "partnership" phase.

Applications of this study: The results of this study may be used as evaluation material regarding the local communities' participation in Lake Toba on tourism destination development. The findings of this study may also be a reference for community-based tourism development in other destinations, to be oriented towards the effectiveness of active participation of local communities.

The originality of the study: The paper is original, and this is the first study to examine the level of local communities' participation in Lake Toba.

Keywords: Local Perspective, Community Participation, Tourism-destination Attributes, Lake Toba, Tourism Development.

\section{INTRODUCTION}

In the past few decades, tourism has experienced significant growth and is believed to have the ability to boost the economy, globally and nationally. UNWTO noted that the tourism industry has contributed as much as nine percent Gross Domestic Product on average throughout the world. Tourism has also opened up various job opportunities; based on research, one out of every eleven jobs in the world is related to tourism. This industry has also contributed to the export sector by the amount of 1.7 trillion US\$, or seven percent of global exports and tourism is the world's thirdlargest export category after chemicals and fuels in 2017 (UNWTO, 2019). Various benefits have encouraged the optimism to increase the growth of tourism with a target of 1.8 billion international tourists' activities around the world by 2030 .

In Indonesia, tourism plays an important role in the growth of the national economy. Hence, tourism has been established as the government's priority program through the Ministry of Tourism in the last few years, with a target of 20 million international tourists and 275 million domestic tourists by 2019. This optimism is supported by the tourism potential of Indonesia, where most of the potential (60\%) is culture, 35\% nature, and 5\% man-made. Aside from this, various policies have been established in order to achieve the target - one such example is the planning of 10 tourism destination priority programs (Kemenpar, 2016). These destinations have the potential to become "New Bali", considering how Bali has been considered a developed tourist destination. As for these ten destinations, then it finally focuses in the five destinations, hereinafter called the 5 super-priority destinations, including the Lake Toba - North Sumatra, Borobudur - Joglosemar, Mandalika - NTB, and Komodo Labuan Bajo - NTT, Likupang Special Economic Zone (KEK/Kawasan Ekonomi Khusus) in TanjungPulisan, North Minahasa, and North Sulawesi (Sakti, 2019).

One of the most aggressive areas for development as a prime tourism destination in North Sumatra, and the natural and cultural tourism potential for one of these prime destinations is Lake Toba, which is located in the Bukit Barisan mountain range. This lake, which is the biggest lake in Indonesia, is located in a super-volcanic caldera. This lake has a length of 100 kilometers (62 miles), 30 kilometers (19 miles) width, and a depth of 1,600 meters (5,200 ft). This lake is 
located in the middle of northern Sumatra Island with a surface height of 900 meters $(2,953 \mathrm{ft})$. Since it was declared as one of the priority destinations, the growth of the tourism industry sector has slowly started to increase. This phenomenon can be seen from the growth of tourist visits to Lake Toba, where the visits of international and domestic tourists to Lake Toba can be considered adequate. In 2015 it attained 114,594 visits (BPS, 2017). In October 2019, there was an increased foreign tourist visit at the ten air entrances. One of them is Kualanamu Airport, North Sumatra up to $37,42 \%$ increased. The third-highest percentage increase was recorded after Lombok and West Nusa Tenggara (BPS, 2019). The accelerated development program of Tourism Destination, Lake Toba has targeted 1,000,000 international tourist visits in 2019. This escalation will be achieved through the enhancement of accessibility and attractions (Kemenpar, 2016).

This target is expected to be able to drive the positive impacts of tourism development for the locals surrounding Lake Toba. Facts based on Badan Pusat Statistik data (BPS, 2016), the profile of local communities in terms of education is still classified as inadequate. The data shows that only $30.19 \%$ of people have received an education for 19 to 24 years (university level), while $69.81 \%$ have received only 16 to 18 years of education (equivalent to high school (SMA)). Tourism is expected to be able to contribute to the human resource quality change, especially through the education sector (vocational or academic). With qualified and competitive human resources, it is hoped that the local communities can actively contribute to the tourism industry development within their area. This is the role or contribution which will later become an important issue and is often used as an indicator of success in sustainable tourism development (Arcana \& Wiweka, 2015; Wiweka et al., 2019), especially in rural areas.

One of the tourism models that has been implemented in Lake Toba that is believed to be able to boost the local contribution is known by the term of Community-Based Tourism (CBT) (Arcana \& Wiweka, 2015). This model is considered able to keep the balance of advantage and impact of tourism in socio-cultural, economic, and environmental aspects (Wiweka \& Arcana, 2016; Arcana \& Wiweka, 2015; Arcana \& Wiweka, 2016). Many countries have implemented this concept, especially for areas that benefit from characteristics of or where the main potential is related to nature (Gabito, 2013: 1; Okazaki, 2008: 512). This model is also said to be a success because it focuses on the active participation of local communities in tourism activities and shares the benefits from these activities (López-Guzmán et al., 2011:72; Suriya, 2010: 2).

Johnson (2010: 150) added that the specific purpose of CBT is to enhance the economic, social, and cultural aspects. Although there has been much research studying the forms of participation and contribution of local communities in the tourism industry, along with the benefits for the local people, Okazaki (2008: 512) stated that research that focuses on studying the level of participation is still very limited. This is the issue that has become the focus of this study, and which, apart from identifying the tourism potential and the form of local communities' contribution in Lake Toba, also attempts to determine the position or level of local participation itself. As for the local communities' participation level, this will be studied through the Arnstein (1969) model.

The results of this study may be used as evaluation material regarding the local communities' participation in Lake Toba on tourism destination development. The findings of this study may also be a reference for community-based tourism development in other destinations, to be oriented towards the effectiveness of active participation of local communities.

\section{LITERATURE REVIEW}

\section{Local Communities' Perceptions Towards Tourism}

The perception of the local communities who live in and around tourism areas is often used as an indicator of the impact and benefits of the tourism industry. Mensah (2012) stated that the perception of the local communities towards tourism development is generally positive, particularly in the social and economic aspects. This is because the local communities directly receive the benefit through job opportunities and the increase in income. However, these responses are usually given by society during the euphoric phase, which is the phase where the local communities receive only the benefits of tourism development without realizing the negative impacts that may surface. Based on Doxey's (1975) Irridex concept, the phase of change in a local community's acceptance of the tourism phenomenon tends to alter as negative effects begin to appear.

\section{Community-Based Tourism}

Although the participation of local communities is one of the main factors in tourism sustainability, this study focuses on the forms of participation themselves. To analyze the levels of local communities' participation, this research utilizes the participation typology model and what is not classified as participation as elaborated by Arnstein (1969: 217), in which he differentiated levels of participation into eight levels. Arnstein (1969: 217) presented a model that illustrates the levels ranging from "participation" to "not participation" as indicators to analyze issues that surface regarding forms of participation from the society.

The first of the eight levels of 'Participation' to "not participation" according to the Arnstein model is 'Manipulation': this level can be categorized into "not participation", in which the purpose of this level is to give knowledge to the society. Support from the society is needed in this phase such as the use of a name as a member in an advisory body. In 
other words, society feels as if they are involved in the management, but in reality, they are not. This level is a deviation of the participation concept which is controlled by the power holder.

The second level is 'Therapy'. Therapy is a level classified as a low level of local communities' participation and displays both dishonesty and unprofessionalism regarding the community's interests, such as has been explained at the manipulation level. In the disguise operated by a group of power holders, the community seems to be involved in the planning. However, in reality, the community is involved in an activity whereby they are the subject of activities to change their mindset. With regards to the third level, 'Informing', the society gains information related to rights, responsibilities, and choices they can take. But the disadvantage of this phase is that there is only a one-way communication without giving the society a chance to give feedback and opinions, and there is no channel to negotiate. In this condition, when information is given suddenly, society has less opportunity to change the plans according to their needs.

The fourth is 'Consultation', where this level is a positive step as a whole form of society's participation. However, the implementation should be combined with other models of participation, or this level of consultation is considered as a pretense without taking into consideration the ideas and the needs of the society. The methods frequently utilized are surveys, inter-environmental meetings, and the hearing of public opinion. The fifth is 'Placation', the level where society starts to receive the opportunity to have an influence, although the acceptance of the provisions made (tokenism) by the holder of power still remains in force. Local communities attain the opportunity to be involved within the government and act as members of local communities' development organizations. However, the number of them in the government organization or body is very small compared to the group of power holders. So, often their opinions are not counted or not listened to.

The sixth level is 'Partnership', where local communities are able to negotiate with the group of power holders. Negotiation in these circumstances is carried out in a form of opinion exchange regarding planning and responsibility in decision-making, organized within mutually agreed rules. The partnership can proceed if local communities own the financial resources to pay for leaders who will manage and apply themselves with the interests of the society at heart. The seventh level is 'Delegation of Power' - at this level, the society's position becomes more dominant because of the delegation of authority. Delegation of Power is a form of negotiation with public officials for planning or specific programs. In this phase, the society holds full control to make sure the planning and the program proceed according to their needs. The power holders need to conduct an offering process that would still appreciate the society's position in this phase, rather than placing pressure on or behaving with antipathy toward the existing programs.

The eighth level is 'Citizen Control', where at this level the society obtains authority or full control on planning and programs for their environment. The society also obtains a guarantee to lead the government or an institution, and to design regulations. They are also able to negotiate with external parties who wish to undertake any changes. The keynote is that they hold full control to plan, conduct, and communicate with third parties for environmental development programs.

Based on the eight levels elaborated above, Arnstein has classified each of the levels into three categories: "not participation' that includes manipulation and therapy; "participation level in the form of accepting several provisions" such as information distribution, consultation, and reference; and the 'real form of participation' which includes a partnership, a delegation of power and control from within the society. Participation levels arranged by Arnstein above could also be utilized in determining the steps needed for much bigger involvement. In addition to this, it can offer help on how we understand the real situation affecting the community within the related tourism destination (Okazaki, 2008: $\underline{513-514)}$.

\section{TOURISM DESTINATION ATTRIBUTES}

The tourism industry is a combination of various disciplines and industry sectors (Jafari in Goeldner and Ritchie, 2009: 24). In addition, the tourism industry could not stand alone without the support of other sectors. Every involved element unites in providing a pleasant and satisfying experience that meets the tourist's needs in a tourism destination (Arcana, 2014:10). Elements that form a tourism product were previously known as 4A (attraction, accessibility, amenities, and ancillary service) (Cooper, et.al., 1993: 81), and as of now, it is known as 6A (Buhalis, 2000: 98). The tourism destination attributes according to Buhalis (2000: 98) are: Attraction - a natural and artificial resource, cultural heritage, and events that become the attraction of a destination to be visited; Accessibility - the whole transportation system, including routes, stations and vehicles provided in a tourism destination to ease the tourist's journey in reaching the tourism destination and tourist attraction; Amenities - the entirety of facilities supporting the tourism industry and providing services for tourists such as accommodation, bars, restaurants, travel bureaus, souvenir shops and travel agents; Available package - the tour packages arranged by intermediaries such as travel agents or travel bureaus; Activities - the entirety of activities that can be enjoyed by the tourists during their trip in the related tourism destination; and Ancillary Service - the tourism infrastructure utilized by the tourists within a tourism destination such as banks, telecommunications, post offices, hospitals, and destination management organization, or tourism bureaus, which act as support to the available tourism facilities. 


\section{METHODOLOGY}

To achieve the research objectives, this study combines two approaches, both qualitative and quantitative, or commonly known as a "multi-method" (Jonker and Pennink, 2010: 92). A qualitative approach is carried out through nonparticipation observation, where researchers observe the Lake Toba tourist area without being involved in the tourism activities carried out by local communities. This technique is carried out to observe the behavior of local people towards tourism activities, while the quantitative approach is carried out by distributing questionnaires to local communities, where the indicator questions are designed based on the destination theory (5A's) and Arnstein's level-of-participation model. The sample is 90 respondents. The sample size is obtained by a calculation of the total population (180,694 people), with the Confidence level or standard deviations at $90 \%$, and as the margin of error is $9 \%$, so the sample size obtained is 83 respondents. The formula used is as follows:

$$
\text { Sample size }=\frac{\frac{z^{2} \times p(1-p)}{e^{2}}}{1+\left(\frac{z^{2} \times p(1-p)}{e^{2} N}\right)}
$$

The results of the questionnaire and observation were then analyzed using a level of community-participation theory which was then presented in the form of a description and design of a chart in Figure 1.

\section{FINDINGS}

Lake Toba is located in the North Sumatra Bukit Barisan mountain range, with a geographical position between $2^{\circ} 21^{\prime} 32^{\prime \prime}-2^{\circ} 56^{\prime} 28^{\prime \prime}$ North Latitude and $98^{\circ} 26^{\prime} 35^{\prime \prime}-99^{\circ} 15^{\prime} 40^{\prime \prime}$ East Longitude. The distance is approximately $176 \mathrm{~km}$ to the south of Medan City, the capital city of North Sumatra province. This lake is bordered by seven regency administrative regions, namely the Regency of Samosir, Toba Samosir, Simalungun, Tapanuli Utara, Humbang Hasundutan, Dairi dan Karo. The water surface area of Lake Toba is $1,124 \mathrm{~km}^{2}$, which is the largest lake in Central Asia. The land area of the water catchment area is $2,486 \mathrm{~km}^{2}$. The surface of the lake is at an altitude of $903 \mathrm{~m}$ above sea level. The maximum length is approximately $50 \mathrm{~km}$, and its maximum width is approximately $27 \mathrm{~km}$. The tourism location of the Lake Toba area is spread along the lake, both close to the water and inland. It is recorded that there are 15 hamlets/villages with the potential of being tourism-supporter regions, and even some villages such as Parapat, Balige, and Pangururan are also business centers.

\section{Destination's attribute in Lake Toba}

\section{Attraction}

The tourist attraction of Lake Toba lies in the diversity of the basic morphological characteristics of Lake Toba, which stretches from northwest to southeast to form two large basins; namely, the northern basin and the southern basin, separated by the presence of Samosir Island. The maximum depth of Lake Toba is approximately $508 \mathrm{~m}$ (the ninth deepest lake in the world), which is located in the northern basin, while the southern basin holds a maximum depth of $420 \mathrm{~m}$. The average depth is $228 \mathrm{~m}$. The whole water volume is approximately $256,2 \mathrm{~km} 3$. In the middle of Lake Toba is Samosir Island with a width of $630 \mathrm{~km} 2$, which is the biggest island in the world that is located within an island. On this island are endemic animals that can only be found within the island, such as the Neolissochilus thienemanni sumtranus fish and Corbicula tobae clams. In addition to the fish that originate from the lake, there are also several types of migrant fish or fish introduced into this lake. Some of the original species in Lake Toba are Aplochilus panchax, Nematochellus pfeifferae, Homaloptera gymnogaster, Channa gachua, Channa striata, Clarias batrachus, Barbonymus gonionotus, $B$. schwanenfeldii, Danio albolineatus, Osteochilus vittatus, Puntius binotatus, Rasbora jacobsoni, Tor tambra, Betta imbellis, Betta taeniata, and Monopterus albus. Another original species whose population is declining is pora-pora fish or undalap (Puntius binotatus).

Parapat City is the tourism center of Lake Toba, where many tourist attractions in the coastal area of Lake Toba can be reached using water transportation. Various tourism attractions in Lake Toba include nature tourism (Lae Pandaroh, Binanga Janji, Sipiso-piso, Sikulikap \& Sampuran Waterfall, and Panguruan hot spring), cultural tourism (Rumah Adat Simalungun), sports tourism, religious tourism (Dairi Regency Taman Iman), and historical tourism (Sidabutar royal burial ground, Sisingamangaraja Palace).

\section{Accessibility}

The length of the national road in the Lake Toba area is $542.98 \mathrm{~km}$, the province road $-172.74 \mathrm{~km}$, the regency road $4,170.59 \mathrm{~km}$, and the length of the ring road in the Lake Toba area is $277.08 \mathrm{~km}$. The road network in the Lake Toba area is generally in good condition, especially the roads that connect between the district capitals; however, some roads along the coastal line of Samosir Island that connect the sub-districts are in poor condition. Some of the roads that connect sub-districts, however, are in relatively good condition. 


\section{Amenities}

The district's biggest economic contributions in the Lake Toba region are the agriculture sector, plantation, farming, fishery, trading, hotels, restaurants (tourism), and transportation. But, unfortunately, in more than $60 \%$ of the area, restaurants are still difficult to find, where more than 50\% of restaurants are located in Balige, $19 \%$ in Laguboti, $17 \%$ in Porsea and the other $14 \%$ are spread throughout Ajibata, Lumban Julu, Pintu Pohan Meranti and Tampahan. A similar phenomenon is also found in the accommodation sector, where more than $70 \%$ (15 hotels/accommodations) are located in Balige, and 30\% are situated in Laguboti (3), Porsea (1), and Uluan (2). As for the total amount of rooms from the entirety of accommodation, there are 293 rooms with 339 beds. This amount is still considered adequate, with the fact that the average occupancy rate in 2014 was $31.13 \%$, or only increased $2.28 \%$ from the previous year.

\section{Available package}

The availability of tour packages to Lake Toba is also provided through various online travel agents (OTA) (Medanholidays, Aurora wisata, tobamuslimtour) and through various tour-package booking applications (traveloka, tripadvisor). Tour packages offered are various, starting from 4 days (3 nights), and 2 days (1 night), to customized packages as per the tourist's request. In addition, tour package offers are also listed on social media such as Instagram, WhatsApp, and Facebook.

\section{Activities}

In the surrounding area of Lake Toba, tourists can enjoy water tourism activities such as sight-seeing, fishing, observation of fish cultivations, and farm animals (poultry, cows, buffalo, horses, goats, sheep and pigs), kayaking and Solu Bolon. As for agro-tourism, there is agriculture and farming (coffee, frankincense, candlenuts, cinnamon, cloves, palm oil and cocoa). In addition, tourists can learn about the culture of the local communities in the Lake Toba region, such as the art of Tortor Batak, Silat (Mossak Batak), Tortor Sigalegale, The Opera Batak, Dance studio, traditional choir, Music instruments (Uning-uningan), Mengali Kerangka Manusia (Manggukalholi), Mangasetaon activity, Mangalahat Horbo, and Mandudu.

\section{Ancillary Service}

Since appointed as National Tourism Destination (Destinasi Pariwisata Nasional) and Top Tourism Destination (Destinasi Pariwisata Unggul) in the tourism sector, together with the establishment of the Lake Toba Region (Kawasan Danau Toba) as a National Strategic Region (Kawasan Strategis Nasional), and seeing the huge potential and importance of Lake Toba as a tourism driving machine, the central government has formed the Lake Toba Tourism Area Management Authority (Badan Otorita Pengelola Kawasan Pariwisata Danau Toba). In this case, on 1 June 2016, President Joko Widodo signed the Presidential Decree (Peraturan Presiden) Nomor 49 Tahun 2016 regarding Lake Toba Tourism Area Management Authority. In this "Peraturan Presiden" is written, to conduct the development of the Lake Toba Tourism Destination Development by forming the Lake Toba Tourism Area Management Authority under and responsible to the President. This is done to ensure that tourism development maintains a role in the development of the local communities' economy (Wardani and Nasution, 2016).

\section{Local's Perspective of Community Participation in Lake Toba}

Data collection techniques of the characteristics of local communities and their opinions about involvement in the tourism sector were carried out through distributing questionnaires to 90 respondents who were randomly selected. Regarding the results of the questionnaires, is as follows.

\section{Respondents' characteristics}

Most of the respondents (89\%) were male, and almost all were married. The majority were in the productive age, with $11 \%$ between the ages of 16 and 29 and 50 and 59 years, $33 \%$ were aged between 30 and 39 years, and $44 \%$ were aged between 40 and 49 years. They were the native inhabitants of Lake Toba (94\%), who mostly completed only secondary education (22\% elementary school and $67 \%$ high school graduates), and only $6 \%$ had an undergraduate education. While $56 \%$ worked as farmers and $11 \%$ were breeders, data shows that they also worked in fields related to tourism (94\%), so it can be assumed that some of them had more than one job in common, with $28 \%$ related to tourist attractions, $6 \%$ transportation, $17 \%$ related to accommodation and souvenirs, and $28 \%$ in other professions. Only $28 \%$ of families worked in the tourism sector. Their average income was IDR 1,078,000 / month.

\section{DISCUSSIONS}

\section{Locals' Perspective of Community Participation Toward Tourism Destination Attributes}

The local communities give their opinions regarding their participation in the tourism activities within their area. Attributes utilized consist of 5A: attractions, accessibility, accommodation, amenities, and ancillary service. Each of the indicators is formed by various questions that present forms or levels of local communities' participation.

A total of $67 \%$ of respondents are aware of the development planning (socialization) and are involved in the planning of tourism attraction development. Sixty-one percent of their families own and or work in one of the tourist attraction 
businesses. As much as $61 \%$ of the respondents are aware that tourism destination development may bear an impact (positive or negative influence), both directly and indirectly on the economy, and have socio-cultural and environmental aspects.

A total of $78 \%$ of respondents are aware of the physical and informational (socialization) accessibility development planning. As much as $67 \%$ are involved in the said planning, where $61 \%$ of them are directly involved in the access development process. Respondents also believe that access development (physical and informational) has an influence (positive or negative) directly or indirectly on the economy (67\%), socio-culture (61\%), and environment (56\%). In addition, as much as $61 \%$ of the respondents are involved in monitoring accessibility development.

A total of $67 \%$ of respondents are aware of the accommodation-development planning, whereas $72 \%$ are involved in the said development, and either own businesses related to accommodation or have family who owns such businesses. As much as $61 \%$ of the respondents also stated working in or have a relative who works in the accommodation business. The majority of respondents also believe that accommodation development has an impact (positive or negative influence) directly and indirectly on the economy (72\%), socio-culture (67\%), and environment (56\%).

The majority of respondents are aware (72\%) and involved (67\%) in the tourism-supporter facilities and amenities development, whereas $72 \%$ of the respondents own their own business related to tourism facilities and amenities (travel agent, etc.), or their family members own a business. A total of $67 \%$ of them have a relative who works in one of the tourism facility and amenity businesses. Most of the respondents stated that the tourism-support facilities- and amenities development has an impact (positive or negative influence) directly and indirectly on the economy (67\%), socio-culture $(61 \%)$, and environment $(67 \%)$.

A total of $67 \%$ of respondents are involved in the planning of village regulations regarding tourism development in Lake Toba, while $61 \%$ of respondents are involved in the monitoring of tourism development, whether individually or organizationally. The majority of the respondents (72\%) also have connections with associations, organizations, or communities related to tourism, whereas $72 \%$ of them are involved in the decision-making regarding tourism development.

After obtaining a description regarding respondents' opinions on their participation in tourism activities in Lake Toba, the next step is to conduct a calculation on each attribute's $(5 \mathrm{~A})$ percentage average. As for the result, it can be elaborated that as many as $64 \%$ of respondents state their involvement in the "Attraction" attribute, $64 \%$ in "Accessibility", whereas $67 \%$ of the respondents stated positive involvement in the "Accommodation" and "Amenities" attributes, and $70 \%$ of respondents were involved in the "Ancillary Service" attribute. If analyzed through the Arnstein (1969) model, this can be described in the chart in Figure 1.



Figure 1: Level of Local Community Participation Chart in Lake Toba

Adapted: Arnstein (1969: 217)

Based on Figure 1, it can be concluded that the local communities' level of participation in Lake Toba is on the "Partnership" level. In this level, society tends to enjoy and feel the advantages of tourism activities. This is shown on the questionnaire data, where the majority of respondents agree with the tourism development (94\%) and activities (94\%) in Lake Toba, while $72 \%$ of respondents do not feel worried by tourism visits to Lake Toba. 


\section{CONCLUSIONS AND RECOMMENDATIONS}

Based on the result and discussion above, it can be concluded that Lake Toba shows potential in its tourism-destination attributes, which include variety and uniqueness of the tourism attraction and activities, and accessibility development (land, water, and air) in the surrounding area of Lake Toba, which stimulates the development of other attributes such as amenities in the form of equalization of accommodation and restaurant development. The availability of tour packages can also be said to be adequate, especially through media technology. As for ancillary services, the existence of Lake Toba Tourism Area Management Authority (Badan Otorita Pengelola Kawasan Pariwisata Danau Toba) can also help the local communities to gain a participatory role in the tourism development of Lake Toba.

Regarding the participation of the local communities, the response of the society to their involvement in Lake Toba tourism-destination attributes can be categorized into the Partnership phase. This is because, based on analysis through Arnstein's model (1969), from the point of view of the local community the level of partnership they feel is that the local community still has room to negotiate with the group of power holders (local government, BOP Lake Toba, and tourism stakeholders). Negotiation in this circumstance takes the form of exchanges of opinions in the planning and decisionmaking responsibilities as arranged in the mutually agreed village regulations. This form of partnership is believed to be able to proceed if the society owns the human resources in the form of a leader who will manage and apply himself to help the interests of the society.

\section{LIMITATIONS}

The limitation of this research lies in the limited number of respondents. This is because the research location has limited transportation access, making it difficult for researchers to reach all areas around Lake Toba. In addition to research that focuses on local communities, especially in remote areas, it requires a special approach, both in terms of culture and society. This adaptation will be much better if this research is carried out in a fairly long duration. In-depth observations will explore more information, related to how local people feel about the development of tourism in their area.

\section{REFERENCES}

1. Anon. (2017). UNWTO Tourism Highlights, 2017 Edition, Tourism Market Trends.

2. Anon. (2015). "BPS Toba Samosir Badan Pusat Statistik". https://tobasamosirkab.bps.go.id. BPS

3. Anon. (2016). "pembangunan destinasi pariwisata prioritas 2016 Kementerian". Kemenpar.

4. Anon. (2016). "Siaran Pers: Kemenpar Siapkan Tenaga Rescue Wisata Danau Toba". Kemenpar. www.kemenpar.go.id/asp/detil.asp?c=16\&id=3513

5. Arcana, K. T. P. (2014). Correlation between the impacts of mice tourism and the destination image through the implementation of sustainable event management concept in Nusa Dua Resort, Bali. Thesis, L'universited' Angers, France. 7-8.

6. Arcana, K. T. P., \& Wiweka, K. (2015). The Impact of Managing Sustainable Event and the Contribution to the Formation of Destination Image at Nusa Dua Resort, Bali. Jurnal Ilmiah Hospitality Management, 6(1), 43-48.

7. Arcana, K. T. P., \& Wiweka, K. (2015). The Potential Development of Community Based Tourism at Ambengan Village, Buleleng Regency, Bali. Journal of Business on Hospitality and Tourism, 1(1), 11. https://doi.org/10.22334/jbhost.v1i1.14

8. Arcana, K. T. P., \& Wiweka, K. (2016). The Perception of Local Community Toward Tourist Accommodation Development, Case Study: Village of Seminyak, Bali. Journal of Business on Hospitality and Tourism, 2(1), 442-457. https://doi.org/10.22334/jbhost.v2i1.79

9. Arnstein, S. R. (1969). A ladder of citizen participation. Journal of the American Institute of Planners, 35(4), 216-224. https://doi.org/10.1080/01944366908977225

10. BPS. (2016). Statistik Indonesia 2016 (Indonesian statistics). Jakarta: Badan Pusat Statistik.

11. BPS. (2017). Badan Pusat Statistik Sumatera Utara.

12. BPS. (2019). Berita Resmi Statistik Perkembangan Pariwisata dan Transportasi Nasional Oktober 2019. http://www.kemenpar.go.id/post/data-statistik-informasi-khusus Retrieved December 19th 2019

13. Buhalis, D. (2000). Marketing the competitive destination of the future. Tourism Management, 21(1), 97-116. https://doi.org/10.1016/S0261-5177(99)00095-3

14. Cooper, C. et al. (1993). Tourism Principles and Practice. England: London, Longman.

15. Doxey. (1975). A causation theory of resident visitor irritants. In The Sixth Annual Conference Proceedings of the Travel Research Association, pp. 195-8.

16. Gabito, O. A. (2013, October). Growing rural employment through community-based tourism. 12th National Convention on Statistics (NCS), EDSA Shangri-La Hotel, Mandaluyong City.

17. Goeldner, Charles R., and Brent Ritchie, J.R. (2009). Tourism Principles, Practice, and Philosophies. Eleventh Edition. New Jersey: John Wiley \& Sons, Inc.

18. López-Guzmán, T., Sánchez-Cañizares, S., \& Pavón, V. (2011). Community-based tourism in developing countries: A case study. Tourismos: An International Multidisciplinary Journal of Tourism, 6(1), pp. 69-84.

19. Johnson, P. A. (2010). Realizing rural community-based tourism development: Prospects for social economy enterprises. Journal of Rural and Community Development, 5(1/2), 150-162. 
International Journal of Tourism \& Hospitality Review elSSN: 2395-7654, Vol 7, No 1, 2020, pp 87-94

https://doi.org/10.18510/ijthr.2020.7110

20. Jonker, J., \& Pennink, B. W. (2010). Looking at research. In the essence of research methodology (1-19). Berlin, Heidelberg, Springer. https://doi.org/10.1007/978-3-540-71659-4_1

21. Kemenpar. (2016). Siaran Pers Festival Danau Toba 2016. http://www.kemenpar.go.id/post/siaran-pers-festivaldanau-toba-2016.

22. Mensah, C. (2012). Residents' perception of socio-economic impacts of tourism in Tafi Atome, Ghana. Asian Social Science, 8(15), 274. https://doi.org/10.5539/ass.v8n15p274

23. Okazaki, E. (2008). A community-based tourism model: Its conception and use. Journal of Sustainable Tourism, 16(5), 511-529. https://doi.org/10.1080/09669580802159594

24. Sakti, Guntur. (2019). Siaran Pers: Rakornas Pariwisata III Bahas Pegembangan 5 Destinasi Super Prioritas. http://www.kemenpar.go.id/post/siaran-pers-rakornas-pariwisata-iii-bahas-pegembangan-5-destinasi-superprioritas.

25. Suriya, K. (2010), July. Impact of community-based tourism in a village economy in Thailand: An analysis with VCGE model. In EcoMod2010 conference, Istanbul, Turkey.

26. Wardani, M. P., \& Nasution, N. A. (2016). Kontribusi Pengembangan Pariwisata Danau Toba Melalui Skema Bop (Badan Otorita Pariwisata) Bagi Masyarakat di Sekitar Danau Toba.

27. Wiweka, K., \& Arcana, K. (2016, May). The impact of tourist accommodation development toward the sociocultural aspects in the Seminyak village, district of Kuta, regency of Badung, Bali (in Perspective of the Local Community). In Asia Tourism Forum 2016-the 12th Biennial Conference of Hospitality and Tourism Industry in Asia. Atlantis Press. https://doi.org/10.2991/atf-16.2016.32

28. Wiweka, K., Indrajaya, T., Wachyuni, S. S., Adnyana, P. P., \& Hanorsian, A. E. (2019). Opportunities and Challenges for the Development of Sustainable Tourism Attraction at Batu Kapal Beach, Central Maluku Lilibooi Village. Advances in Research, 1-14. https://doi.org/10.9734/air/2019/v19i330121 